\title{
A Case Study on Compressive Strength of Geocrete
}

\author{
Dr. S. Siddiraju ${ }^{1}$, M. Pavan Kumar ${ }^{2}$ \\ ${ }^{1}$ Professor and Head, Department of Civil Engineering, Siddhartha Institute of Engineering \& Technology, Puttur, A.P, India \\ ${ }^{2}$ Assistant professor, Department of Civil Engineering, Siddhartha Institute of Engineering \& Technology, Puttur, A.P, India
}

\begin{abstract}
Geocement is obtained by the chemical reaction between silicon (Si) and aluminum (Al) ions and the chemical reaction takes place in the process of polymerization. Geocement doesn't require water at all for mixing and curing processes. It reacts with a special types of binder, known as geobinder in which both are combined to form a hardened mass, known as Geocrete. It can attain high initial strength gain within 3 hours of casting. Geocement is an alkali based cement, prevents the bacterial growth and is ideal for sewerage pipes, water pipes for storage and in food processing industries. This cement has a better acid resistance. Geocement make an ecofriendly environmental product. Geocement plays a vital role to reduce the global warming by reducing carbon dioxide emission by using a liquid binder. The aim of present experimental investigation is to study the properties of geocement i.e. the workability, compressive strength of geocrete. The project deals with M25 grade of Concrete. The test results are prepared by the combination of normal concrete and geocrete. At the age of 28 days, the compressive strength of M25 grade concrete is 32.26 MPa whereas the compressive strength of geocrete at the age of 28 days is $86 \mathrm{MPa}$. The major finding of this study is that the compressive strength of geocrete is more than that of normal concrete.
\end{abstract}

Keywords: Geocrete, Geocement, Geobinder, Concrete and Compressive strength

\section{Introduction}

Geocrete is a construction material composed of geocement and geobinder combined with sand, gravel, crushed stone, or other inert material such as expanded slag or vermiculite etc. The geocement and geobinder form a paste that hardens by chemical reaction into a strong stonelike mass. The inert materials are called as aggregates, and for economy no more cement paste is used than is necessary to coat all the aggregate surfaces and to fill all the voids. The geocrete paste is plastic and easily moulded into any form or trowelled to produce a smooth surface. Hardening begins immediately, but precautions are taken, usually by covering, to avoid rapid loss of moisture since the presence of geobinder is necessary to continue the chemical reaction and increase the strength. Too muchof water produces a porous and weaker concrete. The quality of the paste formed by the geocement and geobinder largely determines the character of the geocrete. The mix design is referred as proportioning of the ingredients of concrete.

Geocrete may be produced as a dense mass which is practically artificial rock, and chemicals may be added to make it waterproof, or it can be made porous and highly permeable for such use as filter beds. Light weight concrete can be achieved by adding an air-entraining chemical. Normally, the full hardening period of concrete is at least 3 hours. TheBogue's compounds i.e. tricalcium aluminates and silicates formed during the hydration of cement results in thegradual increase in strength. Fine aggregate used in concrete was originally specified as roughly angular, but rounded grains are now preferred. Coarse aggregate is usually sharply broken. The weight of Geocrete varies with the type and amount of rock and sand. Concrete produced with trap rock may have a density of $2,483 \mathrm{~kg} / \mathrm{m}^{3}$. Geocrete is stronger in compression than in tension, and steel bar, called rebar or mesh is embedded in structural members to increase the tensile and Flexural Strengths. In much geobinder, however, produces a geocrete that is addition to the structural uses, Geocrete is widely used in precast units such as block, tile, sewer, and water pipe, and ornamental products.

\section{Comparison between Geocementand Portland Cement}

The comparison between geocement and portland cement with different types of properties like compressive strength, setting time, specific gravity, normal consistency, pollution cement to nature, etc., aretabulated in the Table 2.10.

Table 2.10: Comparison between Geocement and Ordinary

\begin{tabular}{|c|c|}
\hline Geocement & Ordinary Portland Cement \\
\hline $\begin{array}{c}\text { The Specific gravity of } \\
\text { Geocement is } 2.15 \text {. }\end{array}$ & $\begin{array}{c}\text { The Specific gravity of } \\
\text { Ordinary Portland Cement is } \\
3.15 \text {. }\end{array}$ \\
\hline $\begin{array}{l}\text { It doesn't require water for } \\
\text { mixing or curing. }\end{array}$ & $\begin{array}{l}\text { It requires water for mixing } \\
\text { and curing. }\end{array}$ \\
\hline Full Setting time is 3 hours. & Full Setting time is 24 hours. \\
\hline $\begin{array}{c}\text { Normal consistency of this } \\
\text { cement is } 41 \% \text {. }\end{array}$ & $\begin{array}{c}\text { Normal consistency of this } \\
\text { cement is } 26 \% \text {. }\end{array}$ \\
\hline $\begin{array}{l}\text { It will attain compressive } \\
\text { strength upto } 88 \mathrm{MPa} \text { for M25 } \\
\text { grade. }\end{array}$ & $\begin{array}{c}\text { It will attain compressive } \\
\text { strength upto } 35 \mathrm{MPa} \text { for M25 } \\
\text { grade. }\end{array}$ \\
\hline $\begin{array}{l}\text { It will reduce } \mathrm{CO}_{2} \text { emission } \\
\text { upto } 65 \% \text { when compared } \\
\text { with other types of cement. }\end{array}$ & $\begin{array}{l}\mathrm{CO}_{2} \text { emission is more when } \\
\text { compared with geocement. }\end{array}$ \\
\hline $\begin{array}{l}\text { No special admixture is } \\
\text { required for geocement. }\end{array}$ & $\begin{array}{l}\text { It requires special admixtures } \\
\text { for Ordinary Portland cement. }\end{array}$ \\
\hline $\begin{array}{l}\text { Waste steel and power } \\
\text { industry are used. }\end{array}$ & $\begin{array}{l}\text { Waste steel and power } \\
\text { industry are not used. }\end{array}$ \\
\hline $\begin{array}{l}\text { Road can be used within an } \\
\text { hour of casting. }\end{array}$ & $\begin{array}{l}\text { Road can't be used within } \\
\text { hour of casting. }\end{array}$ \\
\hline $\begin{array}{l}\text { Skilled labour is not } \\
\text { mandatory. }\end{array}$ & Skilled labour is mandatory. \\
\hline $\begin{array}{c}\text { It has got a significantly better } \\
\text { acid resistance. }\end{array}$ & $\begin{array}{l}\text { It doesn't have better acid } \\
\text { resistance. }\end{array}$ \\
\hline
\end{tabular}




\section{International Journal of Science and Research (IJSR) \\ ISSN (Online): 2319-7064}

Index Copernicus Value (2013): 6.14 | Impact Factor (2015): 6.391

\section{Experimental Investigation}

\subsection{Material Properties}

\subsubsection{Geocement:}

Table 3.1: Physical Propertiesof Geocement

\begin{tabular}{|c|l|c|}
\hline S. No & \multicolumn{1}{|c|}{ Property } & Values \\
\hline 1. & Specific Gravity & 2.15 \\
\hline 2. & Normal Consistency & $41 \%$ \\
\hline \multirow{2}{*}{3.} & Setting times: Initial setting time & $34 \mathrm{mins}$ \\
\cline { 2 - 3 } & Final setting time & $48 \mathrm{mins}$ \\
\hline
\end{tabular}

Table3.2: Chemical Characteristicsof Geocement

\begin{tabular}{|c|l|c|}
\hline S.No & \multicolumn{1}{|c|}{ Property } & Actual Analysis \\
\hline 1. & Appearance & Fine gray dust \\
\hline 2. & Odour & No apparent odour \\
\hline 3. & Melting Point & $>1500^{\circ} \mathrm{c}$ \\
\hline 4. & Solubility in water & Insoluble \\
\hline 5. & Specific gravity & $2-3$ \\
\hline
\end{tabular}

\subsubsection{Geobinder}

Table 3.3: Chemical Composition of Geobinder

\begin{tabular}{|c|l|c|}
\hline S. No & \multicolumn{1}{|c|}{ Chemical Name } & Percentage (\%) \\
\hline 1. & Water $\left(\mathrm{H}_{2} \mathrm{O}\right)$ & 53 \\
\hline 2. & Salt of Silicic acid $\left(\mathrm{Na}_{2} \mathrm{O}_{3} \mathrm{Si}\right)$ & 40 \\
\hline 3. & Additives & 7 \\
\hline
\end{tabular}

Table 3.4: Chemical Characteristics of Geobinder

\begin{tabular}{|c|l|c|}
\hline S. No & \multicolumn{1}{|c|}{ Property } & Actual Analysis \\
\hline 1. & Appearance & Thick Liquid \\
\hline 2. & Colour & Hazy White \\
\hline 3. & Odour & Odourless to clay \\
\hline 4. & $\mathrm{p}^{\mathrm{H}}$ & 11.5 \\
\hline 5. & Specific gravity & 1.5 at $25^{\circ} \mathrm{c}$ \\
\hline 6. & Solubility & Soluble \\
\hline 7. & Boiling point & $105^{\circ} \mathrm{c}$ \\
\hline
\end{tabular}

\subsubsection{Fine Aggregates}

Table 3.5: Properties of Fine aggregates

\begin{tabular}{|c|l|c|}
\hline S. No & \multicolumn{1}{|c|}{ Property } & Values \\
\hline 1. & Specific gravity & 2.59 \\
\hline 2. & Fineness modulus & 2.8 \\
\hline & Bulk density & \\
3. & i) Loose state & $15.75 \mathrm{kN} / \mathrm{m}^{3}$ \\
& ii) Compacted state & $17.05 \mathrm{kN} / \mathrm{m}^{3}$ \\
\hline 4. & Grading of sand & Zone - II \\
\hline
\end{tabular}

\subsubsection{Coarse Aggregates:}

Table 3.6: Properties of Coarseaggregates

\begin{tabular}{|c|l|c|}
\hline S.No & \multicolumn{1}{|c|}{ Property } & Values \\
\hline 1. & Specific gravity & 2.61 \\
\hline & Bulk density & $14.13 \mathrm{kN} / \mathrm{m}^{3}$ \\
2. & i) Loose state & $16.88 \mathrm{kN} / \mathrm{m}^{3}$ \\
\hline 3. & ii) Compacted state & 0.4 \\
\hline 4. & Water absorption, $\%$ & 7.2 \\
\hline
\end{tabular}

\section{Casting of Cubes}

Mix proportion of $0.50: 1: 2.26: 3.81$ is chosen according to its ingredients i.e. theGeobinder, Geocement, fine aggregates and coarse aggregates. In the present study, 9 cubes were prepared forobtaining characteristic compressive strength of cubes. The casted cubes were tested at the age of 3, 7 and 28days. Mix the Geocement and sand with trowel on a nonporous plate until uniform colour is achieved. Place the coarse aggregate in the flat surface and place the cement sand mix upon the aggregates and mix the entire materials thoroughly. Then add geobinder to the mixture. The geobinder - geocement ratio used in this mix is 0.50 . Mixing time is the time elapsed between the water is added to the mix and casting of cubes.

\section{Results}

Tests were conducted to determine the properties of the Geocement and the compressive strength on hardened specimens. Normal procedures were adopted for testing. The experimental program was designed to compare the properties of compressive strength of cubes for M25 grade of geocrete.

\subsection{Properties of Geocement}

The properties of the any type of cement play a vital role in casting of concrete. The important properties of geocement are:

- Fineness of geocement

- Standard consistency of geocement

- Setting time of geocement

\subsubsection{Fineness of Geocement}

The fineness percentage of the geocement is $94 \%$.

\subsubsection{Standard Consistency of Geocement}

The percentage of geobinder to obtain a geocement paste is $41 \%$.

\subsubsection{Setting Time of Geocement}

The setting time plays a vital role on any type of cement.

The setting times are categorized into two types:

a) Initial setting time

b) Finial setting time

\section{a) Initial Setting Time}

The initial setting time of geocement is 34 mins.

b) Finial Setting Time

The finial setting time of geocement is 48 mins.

\subsubsection{Specific Gravity f Geocement}

The specific gravity of geocement is 2.15

\subsubsection{Compressive Strength}

The variation of the cube compressive strength of M25 gradeconcrete and geocretewith age for a given geocement is as shown in Fig 5.1.and the test results are formulated in table 5.1. The cube compressive strength is the average of three test specimens. It can be observed that the compressive strength of geocrete is more than that of normal concrete.

\section{Volume 5 Issue 5, May 2016}


International Journal of Science and Research (IJSR)

ISSN (Online): 2319-7064

Index Copernicus Value (2013): 6.14 | Impact Factor (2015): 6.391

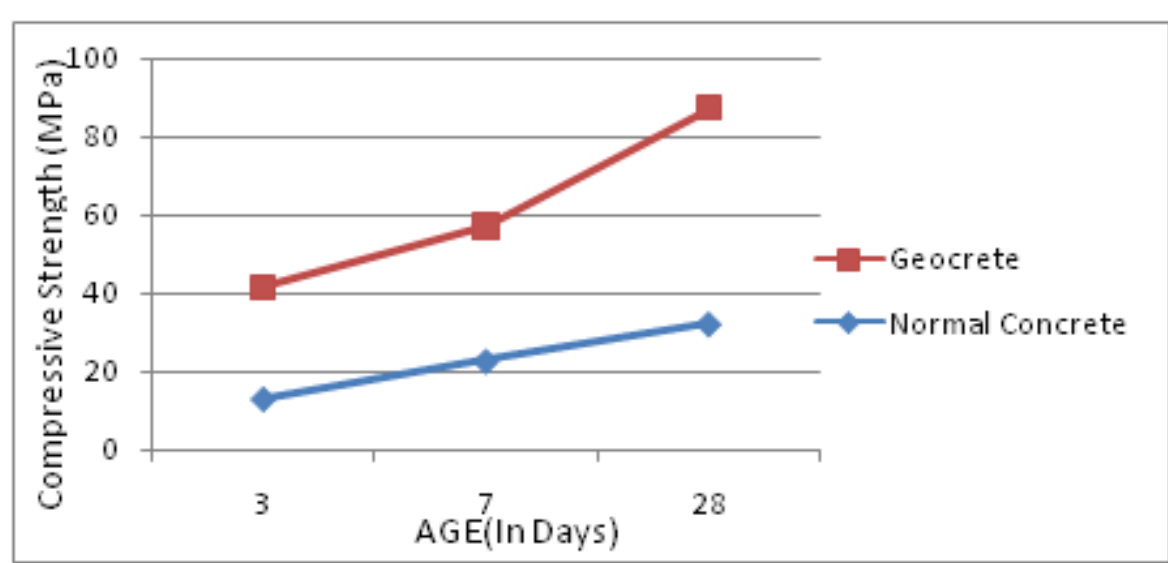

Figure 5.1: Variation of Compressive Strength between Geocrete and Normal Concrete

Table 5.1: Characteristic Compressive Strength of Cubes in $\mathrm{MPa}$

\begin{tabular}{|c|c|c|c|c|}
\hline \multirow{2}{*}{ S.No } & \multirow{2}{*}{ Concrete Mix } & \multicolumn{3}{|c|}{$\begin{array}{c}\text { Compressive Strength } \\
\text { (MPa) }\end{array}$} \\
\cline { 3 - 5 } & & 3 Days & 7 Days & 28 Days \\
\hline 1. & Normal Concrete & 12.94 & 22.65 & 32.26 \\
\hline 2. & Geocrete & 28.64 & 34.44 & 86 \\
\hline
\end{tabular}

\section{Conclusions}

The results of the experimental study show that the compressive strength of geocrete is more than that of the normal concrete.

1) This technology is advantageous in terms of simplicity and cost. The adavantages come from low cost of geocement constituents, since a wide range of industrial waste and by-products as well as widely available natural raw materials are used, and the facilities that are commonly used now can be also involved. The results of feasibility study showed that the manufacturing cost of the compound is about $15-30 \%$ lower (comparison based on raw materials cost).

2) Based on the test results, it can be concluded that the compressive strength of geocrete for various days are i.e. the 3-daycompressive strength is $28 \mathrm{MPa}$, the 7-day compressive strength is $34.4 \mathrm{MPa}$ and the 28-day compressive strength is $86 \mathrm{MPa}$.

3) It is very interesting to note that the compressive strength achieved bygeocrete is very high when compared with the controlled concrete.

4) The increase in strength of geocrete is due to increase of percentage of silica-oxide in the geocement.

5) The road constructed by using the geocrete, can be allowed for passage of vehicleswithin 3 hours.

6) Geocrete is an eco-friendly concrete because it will reduce the carbon dioxide emission upto $65 \%$ when compared with normal concrete.

7) The geocement has low specific gravity.

8) The setting action of geocrete is quick when compared with conventional concrete.

9) The geocement used in geocrete has a significantly better acid resistance when compared with other cements.

\section{References}

[1] Glukhovsky V D .Soil Silicate Articles and Constructions. Budivelnik Publish., Kiev, USSR,1967, $154 \mathrm{pp}$.

[2] Glukhovsky V D. ET AL: Alkaline and Alkaline-Earth Alumosilicate Hydraulic Binders and Concretes, VischaShcola Publ., Kiev, USSR, 1979, 232pp.

[3] J.Davidovits (2008),First book on Geoploymer Chemistry \& ApplicationsInsituGeopolymer, SaintQuentin, France, ISBN 2-951-14820-1-9.

[4] M.S.Shetty (2012), "Concrete Technology, Theory and Practice",S.Chand Publications, pages 136, 158-163, 222, 227, 421-423.

[5] M.L.Gambhir (2009), "Concrete Technology, Theory and Practice", McGraw Hill Publications, Pages 154.

[6] IS 10262-2009. "Concrete Mix Proportioning - Guidelines (First Revision)". Bureau of Indian Standards, New Delhi.

[7] IS 516:1959. "Methods of Tests for Strength of Concrete". Bureau of Indian Standards, New Delhi, India.

[8] IS 8112:1989. "43 Grade Ordinary Portland Cement Specifications". Bureau of Indian Standards, New Delhi, India.

[9] IS 383:1970 (Reaffirmed 1997) Specification for Coarse and Fine Aggregates from Natural Sources forConcrete. Bureau of Indian Standards, New Delhi, India. 